\title{
Technical Overview Of Biogas Utilization as Fuel of Boat Engine
}

\author{
Nilam Sari Octaviani and Semin
}

\begin{abstract}
The depletion of world energy reserves and the increasing levels of environmental pollution, increase human creativity. Discoveries on environmentally friendly renewable energy-making technologies are increasingly widespread. One of them is the manufacture and utilization of biogas as an alternative fuel. Biogas is one of renewable energy sources with bio gas production process from organic material like cattle dung with the help of bacteria decomposers. By conducting a literature study on biogas utilization and calculation analysis, biogas application was applied as an outboard fuel engine with 10 horse power in a boat capable of crossing for 10 minutes with a capacity of 1 to 2 passengers, such as private boats owned by coastal communities or boats used by traders on floating markets in the Kalimantan area.
\end{abstract}

Keywords—Biogas utilization, boat, cattle dung, engine.

\section{INTRODUCTION}

$\mathrm{T}$ he increasing demand for goods and services leads

to an increase in human needs for the use of water transport. Indonesia is known as an archipelagic country with $2 / 3$ of its territory is the territorial waters. Indonesian people utilize boats, boats and other means of water transportation as a tool for human and goods crossing, trade aids on traditional floating markets and much more. This situation causes the consumption of diesel and gasoline as the fuel of the ship's engine also increased. With the enormous dependence on fossil fuels derived from petroleum, surely there must be an attempt to divert into other renewable energy sources.

In recent years, there have been many attempts by the Indonesian government to change the use of fossil fuels to gas fuel, for example kerosene to LPG gas conversion that is now being used in household activities. Another program that has been implemented is fuel used by vehicles from gasoline or diesel oil to gas, however it does not work optimally. This program motivates the formation of other similar programs, namely the converting of fuel for ship engines and boats that are diesel fuel and gasoline into gas, both derived from natural gas and biogas.

Biogas is a renewable energy source with bio-gas production process from organic material with the help of bacterial decomposers. The degradation process of this organic material does not involve oxygen (anaerobic digestion), where the result is mostly methane gas produced by anaerobic fermentation of organic matter. Biogas can be produced from market waste, agricultural waste, wastewater, manure and animal waste. In Indonesia, however, most biogas manufacturing applications use livestock manure [1].

The invention of simple applicative technology in generating and utilizing biogas makes this technology stoutly applied in the community because it has an economic advantage [2]. Most of biogas application is used as household stove fuel. The application of biogas

Author name is with Faculty of Marine Technology, Institut Teknologi Sepuluh Nopember Kampus ITS Sukolilo (60111), Surabaya, Indonesia. E-mail: semin@its.ac.id that is applied as a fuel for ships is still quite rare or even not yet exist. Therefore, the application of biogas as a substitute for outboard motor fuel in boats used for short range crossings is further studied.

\section{LITERATURE REVIEW}

A. Biogas

Biogas is a type of gas fuel (biofuel) and renewable fuel produced by anaerobic digestion or anaerobic fermentation of organic matter with the help of methane bacteria such as methanobacterium sp. Materials that can be used as raw materials for the manufacture of biogas are organic materials instead of fossil, dirt, organic solid waste from urban activity and others. However, in Indonesia biogas is usually made from manure of buffalo, cows, goats, horses, pigs and other livestock.

According to Sunaryo [3], the main content of biogas is methane gas $(\mathrm{CH} 4)$ with concentrations of $50 \%-80 \%$. Gases in biogas that can act as fuel are methane gas (CH4), Hydrogen gas (H2), Carbon monoxide (CO) gas and small amounts of Nitrogen (N2), Oxygen (O2) and Hydrogen sulfide (H2S).

1) Biogas Production Process

The process of making biogas is through a fermentation process of forming methane gas under anaerobic conditions with the aid of bacteria in a digester. So it will produce methane gas $(\mathrm{CH} 4)$ and carbon dioxide gas $(\mathrm{CO} 2)$ which is larger than hydrogen gas (H2), nitrogen gas N2) and hydrogen sulfide gas (H2S).

According to Elizabeth at al [5], the process of fermentation of organic materials takes 7-10 days to produce biogas with an optimum temperature of $35^{\circ} \mathrm{C}$ and optimum $\mathrm{pH}$ in the range of 6.4-7.9. Biogas is made from cow dung contains $55-65 \%$ $\mathrm{CH} 4$ gas, $30-35 \% \mathrm{CO} 2$ gas and little hydrogen gas (H2), nitrogen gas (N2) and other gases. The heat produced is $600 \mathrm{BTU} / \mathrm{cuft}$. Meanwhile, biogas is made from natural gas containing $\mathrm{CH} 4$ gas of $80 \%$ with heat of 1000 BTU/cuft. According to Sunaryo [3] the $\mathrm{CH} 4$ gas content of biogas can be increased by separating $\mathrm{CO} 2$ gas and $\mathrm{H} 2 \mathrm{~S}$ gas which are corrosive. Making biogas is began by incorporating organic matter into the digester, so that anaerobic bacteria will 
decompose the organic material and produce a gas called biogas. According to Aremu et al [4], biogas can be produced at 7-10 days after the iodigester is fully charged, and reaches its peak on days 20-25. The biogas that has accumulated in the digester is passed through the gas pipeline to the gas storage tank or directly to the site of use, for example is the cooker.

2) The advantages of Biogas

Biogas can be used in the same way as other flammable gases. Combustion is done by mixing biogas with oxygen $(\mathrm{O} 2)$. According to Sunaryo [3], to obtain optimal combustion results need to be purified / filtering process because biogas contains some other unfavorable gas. The exhaust gas generated from the biogas combustion process is environmentally friendly, so the use of biogas as a fuel can reduce the pollution that occurs in the environment.

According to Aremu et al [4] and Semin [12], there are other advantages obtained in the manufacturing process of biogas, namely the production of sludge that can be used as a fertilizer because it is enriched with compost that can increase the nutrient of agricultural land. When the biogas forming process is from organic materials in biogas reactors, it can be degraded with the help of enzymes and bacteria.

\section{B. The Working Principle of Engine}

According to Daryanto [7], combustion is a process whereby the fuel mixed with oxygen in the air causing heat to press and then generates mechanical energy. It can be concluded that engine is a component used to convert the chemical energy of fuel into thermal energy, and use that energy to perform mechanical work. Engine are divided into several types based on the fuel combustion process, namely external combustion engine and internal combustion engine.

\section{External Combustion Engine}

The external combustion engine is an engine that the fuel combustion process occurs outside the engine, so to carry out combustion is used its own mechanism. The heat from the fuel combustion is not directly converted to power, but through the conductor medium, and then it converted into mechanical power. For example, steam engines and steam turbines.

\section{Internal Combustion Engine}

The internal combustion engine is the engine that the fuel combustion process occurs inside the engine, so the heat from the combustion result is directly converted into mechanical power. For example, gas turbine, diesel engine and gas transmitter propultion engine.

Combustion is also called a chemical reaction between fuel and oxygen. Although there is a process of mixing fuel with oxygen, chemical reactions do not necessarily occur. There are several other requirements that must be met. To get the maximum burning process required a perfect process, namely with the following conditions

a. The quantity of oxygen in the supply to the combustion chamber is sufficient

b. Oxygen and fuel are completely mixed

c. The air-fuel mixture is maintained above its ignition temperature

\section{Boat Engine}

Boat engine is one type of internal combustion engine that is used as a driving machine on the boat crossing. This type of machine uses gasoline. The structure and the application of boat engine are presented on Figure 1.

The working principle of boat engine is similar as the otto engine. Its working process is described down below:

1. Gasoline-air mixture are injected into engine combustion chamber when the piston position is bottom dead center (BDC).

2. Then the compression stroke occurs when the piston moves to top dead center (TDC). At the of compression stroke, spark plug engine and air fuel mixture are reacted and then the combustion process occurs.

3. Power stroke is a result of the explosion in the combustion process that occurs in the cylinder. At this stroke, the piston moves to bottom dead center

4. And finally, the piston back to the position of top dead center performs the exhaust step on the combustion gas that occurs in the cylinder.

\section{METHODS}

The method used in writing this paper is a study of literature on journals to obtain data and information related to the theme of the paper.

\section{DISCUSSION AND RESULT}

\section{A. Boat Engine Specification}

Boat engines commonly used on short-range boats, it is about 5-20 HP. The power of engine boat is usually capable of carrying 4-10 passengers. This research uses an engine boat as the object. Its specification are described on Table 1.

\section{B. Installation System Plan}

In order to be used as engine alternative fuel, we need to design the installation system of biogas from the storage into the engine. The installation system starts from the opening of the valve so the biogas in the storage tank passes through the hose. Biogas that flows into the engine has a certain pressure that will be read on the pressure gauge. Furthermore, biogas will enter the mixing component. Biogas and air will be mixed together before through the intake valve. Next, biogas and air mixture enter the combustion chamber when the intake stroke of engine. The biogas air mixture will be compressed and at the end of the compression stroke, the compressed biogas air mixture will be contacted with the spark plug and 
produce the flame, so the combustion process can occur. The biogas installation system plan is presented in Figure 2.

The components information of biogas installation system that are presented on Figure 2, namely:

1. Biogas Storage Tank,

2. Valve of Biogas Tank

3. Pressure Gauge

4. Pipe

5. Biogas-air Mixturer

6. Boat Engine

\section{Calculation of Biogas Utilization}

According to Haryati [6], methane gas as the main component of biogas is the odorless and colorless gas which, when burned, will produce heat energy of about $1000 \mathrm{BTU} / \mathrm{ft} 3$ or $252 \mathrm{Kcal} / 0.028 \mathrm{~m} 3$. Biogas can be converted into several forms of energy, such as heat energy or with the help of a generator converted into electrical and mechanical energy. Table 2 presents the biogas enegy conversion and biogas utilization.

Based on Table 1, it is known that biogas of $1 \mathrm{~m}^{3}$ can be used for carrier (motor) with power of $1 \mathrm{HP}$ with 2 hours operation time. As the calculation above, $1 \mathrm{HP}$ equals to $0.736 \mathrm{~kW}$. When analyzed further, the boat across the short distance does not have a tank large enough to be able to store biogas as much as $1 \mathrm{~m}^{3}$. The tank on the boat is usually small in size which is only able to store fuel in liquid form which is used for 1 times the crossing route (1 return trip). For that purpose, a small portable biogas digester is used for biogas storage tanks as a boat fuel.

In the design plan, the portable biogas storage tank will be made by using a paint bucket of 20 liters. When converted for use on outboard engines, the calculation is obtained as follows:

It is known that:

- 20 liter paint bucket

$$
\begin{array}{ll}
1 \text { liter } & =0,001 \mathrm{~m}^{3} \\
20 \text { liter } & =0,02 \mathrm{~m}^{3}
\end{array}
$$

- Power of boat engine $=10 \mathrm{HP}$

- $1 \mathrm{~m}^{3}$ biogas = $1 \mathrm{HP}$ engine for 2 hours engine operation

So :

$$
\begin{aligned}
-10 \mathrm{HP} & =10 \mathrm{~m}^{3} \text { biogas for } 2 \text { hours } \\
& =5 \mathrm{~m}^{3} \text { biogas peer } 1 \text { hour }
\end{aligned}
$$

$$
\begin{aligned}
& =5 / 60 \\
& =0,083 \mathrm{~m}^{3} \text { biogas peer minute }
\end{aligned}
$$

If the plan use 5 HP boat engine, so:

$$
\begin{aligned}
5 \mathrm{HP} & =2,5 \mathrm{~m}^{3} \text { biogas per hour } \\
& =2.5 / 60 \\
& =0,042 \mathrm{~m}^{3} \text { biogas per minute }
\end{aligned}
$$

If in every 1 trip crossing, it takes 10 minutes, so the boat need $0,42 \mathrm{~m}^{3}$ biogas per trip crossing. It means that the amount of portable storage tank of biogas in one trip crossing are:

$0,02 \mathrm{~m}^{3}=1$ portable storage tank

$0,42 \mathrm{~m} 3= \pm 21$ portable storage tanks

With the amount of 21 biogas storage tanks used on boats in a single crossing, it will reduce the capacity of people who can carry the boat.

\section{CONCLUSION AND RECOMMENDATION}

Based on the calculation, it can be concluded that:

1. The conversion of gasoline into biogas on the boat engine found on the boat crossing can be done on boats that use boat engines with power less than 5 HP.

2. The conversion of gasoline into biogas on boat engines found on crossing boats can be done on short-range crossing boats that have travel time of less than 10 minutes.

3. Boats that use biogas fuel have a small carrying capacity, so the conversion of gasoline to biogas in outboard engines found on boat crossing can be done on boats with capacity of 1-2 people, such as private boats owned by coastal communities or boats that used by traders on floating markets in Banjarmasin, South Kalimantan.

As for the recommendations given for perfection in making this paper, that is:

1. We have known about the biogas specification and fuel specification for each engine on Table 2 to determine the fuel consumption on engine, so the application of biogas as alternative fuel could be calculated precisely

2. Special system design is required to apply biogas to the ship's fuel system, in the form of a special tube design, in which biogas is stored in liquid form and then degasified it for the combustion process on the boat engine 

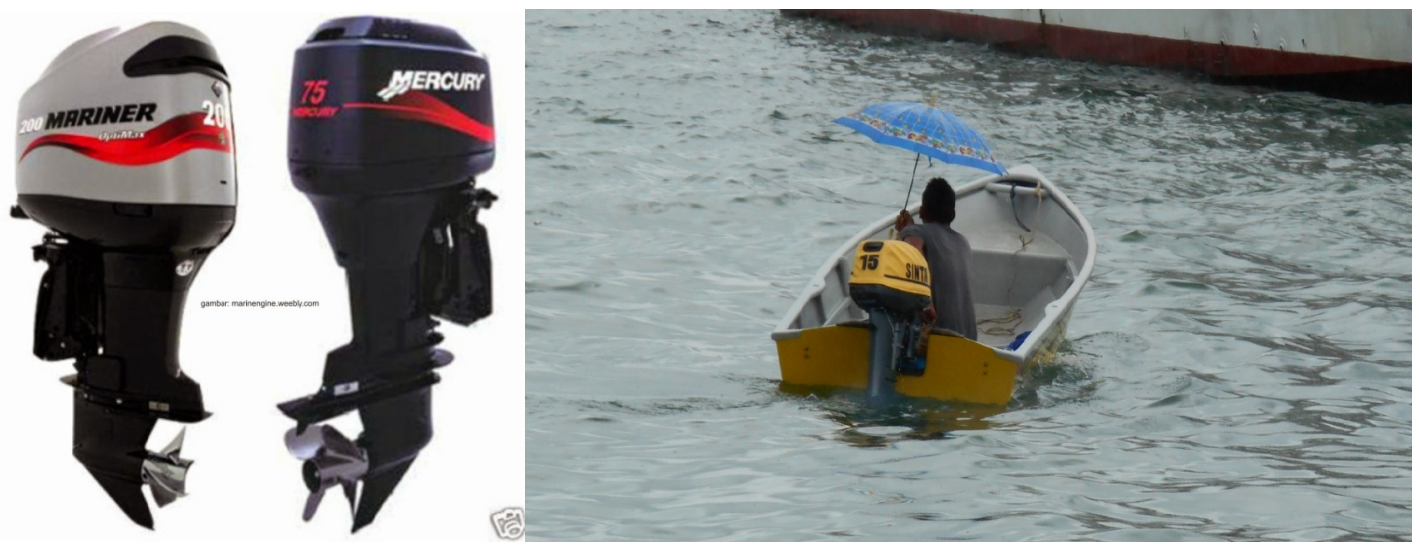

Figure 1. Boat engine

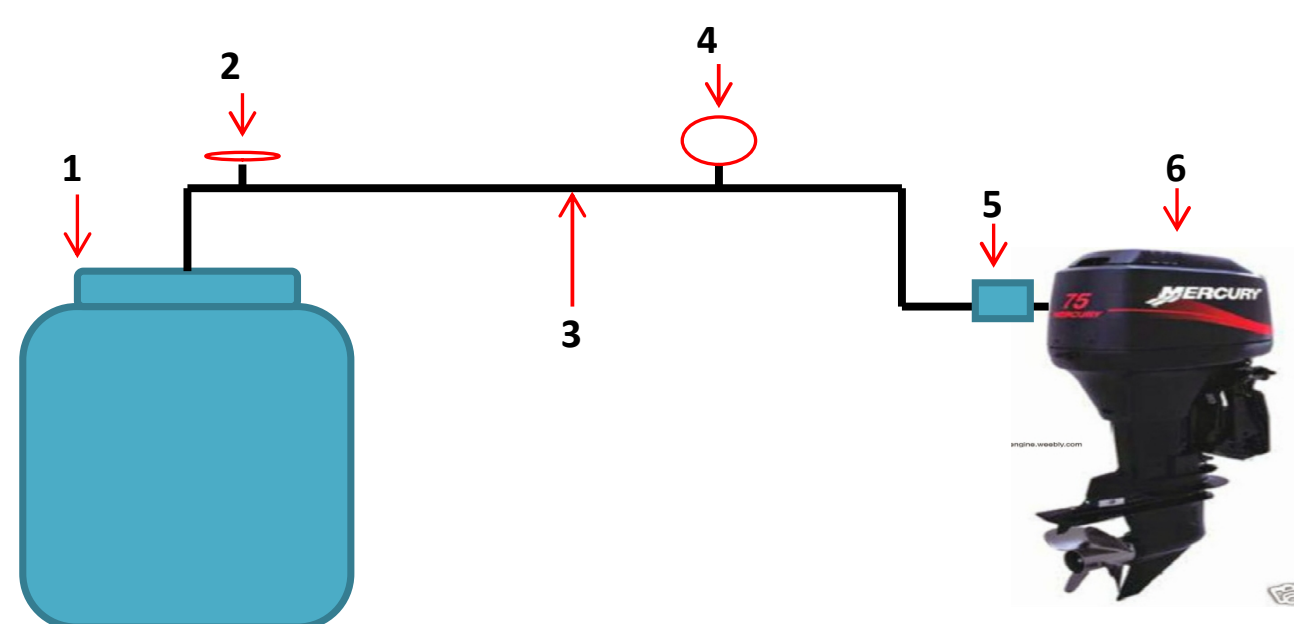

Figure 2. Biogas Installation System Plan

Table 1. Engine Specification

\begin{tabular}{ll}
\hline Engine Specification & Data \\
\hline Power & $10 \mathrm{HP}=7,36 \mathrm{~kW}$ \\
Engine Type & $2 \mathrm{stroke}$, in-line 1 \\
Displacement & $103 \mathrm{~cm}^{3}$ \\
RPM Max & $4500-5500 \mathrm{rpm}$ \\
Bore x Stroke & $54.0 \times 45.0$ \\
\hline
\end{tabular}

Table 2. Biogas Energy Conversion and Utilization [6]

\begin{tabular}{ll}
\hline Utilization & Biogas Energy in every $\mathbf{1 ~ m}^{\mathbf{3}}$ \\
\hline Lighting & Compare-able to 60 watt for 6 hours \\
Cooking & Compare-able to cooking 3 dishes for 5-6 people \\
Alternative fuel & Compare-able to 0.7 kg gasoline \\
An engine fuel & Compare-able to running an engine $1 \mathrm{HP}$ for 1 hour \\
Electricity & Compare-able to $1.25 \mathrm{KWH}$ electricity \\
\hline
\end{tabular}

\section{ACKNOWLEDGEMENT}

The authors would like to be obliged to Department of Marine Engineering, Institut Teknologi Sepuluh Nopember for providing laboratory facilities.

\section{REFERENCES}

[1] Semin, A.Z.M. Fathallah, Beny Cahyono, I M. Ariana, S. Sutikno, Kajian 2014, Pemanfaatan Kotoran Sapi sebagai Bahan Bakar Biogas Murah dan Terbarukan untuk Rumah Tangga, Jurnal Sains dan Teknologi Industri 11(2), 212-220

[2] Kuncahyo P., Fathallah A.Z.M., Semin, 2013, Analisa prediksi potensi bahan bakar biodiesel sebagai suplemen bahan bakar motor diesel di Indonesia, Jurnal Teknik ITS, Vol 2 no 1.

[3] Sunaryo, 2014, Uji Eksperimen Pemurnian Biogas sebagai Pengganti Bahan Bakar Motor Bensin , Jurnal PPKM II , 123130
[4] Aremu, M .O. dan Agarry S. E. , 2012, Comparison of Biogas production from Cow dung and Pig dung Under Mesophilic Condition, International Refereed Journal of Engineering and Science (IRJES), 16-21

[5] Elizabeth R. Rusdiana S., Efektifitas Pemanfaatan Biogas Sebagai Sumber Bahan Bakar dalam Mengatasi Biaya Ekonomi Rumah Tangga di Pedesaan

[6] Hartati T. , 2006 , Biogas : Limbah Peternakan yang Menjadi Sumber Energi Alternatif

[7] Daryanto, 2003 , Motor Bakar untuk Mobil , Jakarta , Rineka Cipta dan Bina Adiksa

[8] Hery A. F. , Septiropa Z. , Rinsyah S. dan Romadhi F. , 2011 , Pemanfaatan Biogas/Landfillgas sebagai Bahan Bakar Mesin Bensin 1 Silinder 4 Langkah, Jurnal Teknik Industri, Vol. 12 No. 2, 162-168

[9] Wiratno T. , Rahardjo S. , Suwignyo J. , 2012 , Perhitungan Daya dan Konsumsi Bahan Bakar Motor Bensin Yamaha LS 100 cc

[10] Saputri Y.F. , Yuwono T. , Mahmudsyah S. , 2014 Pemanfaatan Kotoran Sapi untuk Bahan Bakar PLT Biogas 80 
International Journal of Marine Engineering Innovation and Research, Vol. 2(2), Mar. 2018. 171-175

(pISSN: 2541-5972, eISSN: 2548-1479

KW di Desa Babadan Kecamatan Ngajum Malang , Jurnal Teknik POMITS Vol. 1, No 1, 1-6

[11] Hartanto A. , Susanti V., Subekti R.A. , Saputra H. M. , Rijanto E. , Hapid A. , Program Konversi dari BBM ke BBG untuk Kendaraan, LIPI, Bandung.

[12] Semin, 2015, Analysis of biogas as an alternative fuel for electric generator engine in bawean island - Indonesia, International Journal of Applied Engineering Research, Vol 10 (15), pp 35313-35317. 